\title{
PENGARUH YOUTUBE DI SMARTPHONE TERHADAP PERKEMBANGAN KOMUNIKASI INTERPERSONAL ANAK
}

\author{
Asaas Putra ${ }^{1}$, Diah Ayu Patmaningrum ${ }^{2}$ \\ ${ }^{1,2}$ Fakultas Komunikasi dan Bisnis, Program Studi Ilmu Komunikasi, Telkom University \\ ${ }^{1,2} \mathrm{Jl}$. Telekomunikasi, Terusan Buah Batu, Bandung, Jawa Barat, 40257, Indonesia \\ ${ }^{1,2}$ No. Telp./HP: (022)7564108 \\ E-mail:1'asaasputra@telkomuniversity.ac.id, ${ }^{2}$ dapayu31@gmail.com
}

Naskah diterima pada tanggal 29 Oktober 2018, direvisi tanggal 12 November 2018, disetujui tanggal 14 November 2018

\section{THE INFLUENCE OF YOUTUBE ON SMARTPHONE TOWARDS DEVELOPMENT OF CHILD'S INTERPERSONAL COMMUNICATION}

\begin{abstract}
Nowadays, applications that are used on smartphones are increasing which are directly proportional to the development of science, it's not only for adults, but kindergarten children have used smartphones every day to seek entertainment through the Youtube application. This research was conducted to find out the influence of Youtube application on smartphones towards the development of kindergarten children's interpersonal communication in the City of Bandung. This research is also expected to answer the issue concerning the influence of technology towards the communication skills of kindergarten-aged children, which is widespread without clear data and research. The method used is quantitative with descriptive research type. The use of quantitative method so that the data obtained can be accurate, measurable, and reliable. This research involves one independent variable and one dependent variable. The sampling using probability sampling formula with Slovin approach with the number of respondents 70 kindergarten children. The data analysis technique used is descriptive and simple linear regression analysis. The conclusions of this study, show that accessing Youtube on smartphones for kindergarten children in City of Bandung which is carried out every day, can have a positive influence on the development of kindergarten children interpersonal communication skills.
\end{abstract}

Keywords: interpersonal communication, youtube, kindergarten.

Abstrak. Saat ini aplikasi yang digunakan pada smartphone semakin berkembang, dan berbanding lurus dengan perkembangan ilmu pengetahuan, bukan hanya orang dewasa, namun anak Taman Kanak-Kanak (TK) sudah menggunakan smartphone setiap harinya untuk mencari hiburan melalui aplikasi Youtube. Penelitian ini dilakukan untuk mengetahui seberapa besar pengaruh aplikasi Youtube di smartphone terhadap perkembangan kemampuan komunikasi interpersonal anak TK di Kota Bandung. Penelitian ini juga diharapkan menjawab isu yang beredar tentang pengaruh teknologi terhadap kemampuan komunikasi anak usia TK yang beredar tanpa berdasarkan data dan riset yang jelas. Metode yang digunakan ialah kuantitatif dengan jenis penelitian deskripsi. Penggunaan metode kuantitatif agar data yang didapatkan bisa akurat, terukur, dan teruji. Penelitian ini melibatkan satu variabel independen dan satu variabel dependen. Pengambilan sampel menggunakan rumus probability sampling dengan pendekatan Slovin dengan jumlah responden 70 anak TK. Teknik analisis data adalah deskripsi dan analisis regresi linear sederhana. Simpulan penelitian ini, pengaksesan youtube di smartphone untuk anak TK di Kota Bandung yang dilakukan setiap harinya bisa memengaruhi perkembangan kemampuan komunikasi intepersonal anak.

Kata kunci: komunikasi interpersonal, youtube, anak TK. 


\section{PENDAHULUAN}

Smartphone merupakan salah satu bentuk teknologi komunikasi dan informasi yang mudah ditemukan pada saat ini. Bisa terlihat hampir semua orang sudah memiliki smartphone, khususnya di daerah perkotaan. Menurut Shiraishi dalam Pratama (2017), smartphone merupakan telepon genggam yang memiliki sistem operasi untuk masyarakat luas, dimana pengguna dapat menambahkan atau mengubah aplikasi sesuai dengan keinginannya. Smartphone juga diartikan sebagai telepon genggam yang menyerupai komputer mini yang memiliki kapasitas sama dengan sebuah telepon.

Penggunaan smartphone bukan hanya sebagai alat komunikasi saja, melainkan mendorong terbentuknya interaksi yang sama sekali berbeda dengan interaksi tatap muka. Interaksi yang terbentuk seperti dipercepat alurnya melalui suara dan tulisan yang dikirim. Kecanggihan smartphone menawarkan berbagai macam fitur dan aplikasi serta mampu mengakses internet dilengkapi juga dengan kamera dengan berbagai jenis resolusi, mulai yang paling rendah sampai paling tinggi. Kecanggihan smartphone sudah hampir menyerupai komputer, sehingga smartphone dapat menginstall berbagai program dalam komputer seperti Microsoft Office, Winamp, serta media sosial seperti Facebook, Twitter, Line, Whatsapp, Instagram, Youtube, dan programprogram lain yang dapat memudahkan dan memanjakan kehidupan manusia.

Wahyudi (2017) menyebutkan pengguna smartphone di Indonesia pada tahun 2017 mencapai 86.600.000 dan lembaga riset digital marketing Emarketer memperkirakan pada 2018 jumlah pengguna aktif smartphone di Indonesia akan mencapai lebih dari 100.000.000 orang. Dengan jumlah sebesar itu, Indonesia akan menjadi negara dengan pengguna aktif smartphone terbesar keempat di dunia setelah Cina, India, dan Amerika. Data tersebut menunjukkan bahwa kehidupan manusia tidak lepas dari smartphone dan internet, bahkan saat ini apabila seseorang tidak pernah menggunakan internet dan telepon akan dianggap ketinggalan zaman. Kebutuhan informasi dan gaya hidup masyarakat modern pada era globalisasi menjadi faktor mendorong para pelajar menggunakan smartphone. Fitur di smartphone juga membuat seseorang menjadi kecanduan.

Media sosial berbasis video yang paling sering diakses di smartphone adalah Youtube. Mulai dari berita, klip musik terbaru, komedi, semua ada di Youtube. Situs Youtube menyediakan berbagai informasi berupa video, termasuk di dalamnya audio. Youtube ditujukan bagi mereka yang ingin mencari informasi dalam bentuk video. Selain mencari video, pengunjung situs ini juga dapat mengunggah video mereka ke Youtube dan membagikannya ke seluruh dunia (Muhaemin, 2017).

Youtube merupakan sebuah platform untuk memublikasikan video, platform ini dapat diakses oleh semua orang di negara manapun. Platform ini resmi berdiri pada tahun 2005. Pendirinya adalah Chad Hurley, Steve Chen, Jawed Karim dimana mereka bertiga adalah mantan karyawan PayPal. Kemudian platform Youtube dibeli oleh Google dan diperkenalkan kembali pada tahun 2006. Berdasarkan riset yang dilakukan oleh hootsuite sangat jelas bahwa Youtube sangat digemari oleh masyarakat Indonesia, dengan menduduki most active social media. Youtube telah memudahkan miliyaran orang dalam menemukan, menonton, dan membagikan berbagai macam video. Youtube menyediakan forum bagi orang-orang untuk saling berhubungan, memberikan informasi, menginspirasi orang lain di seluruh dunia, serta bertindak sebagai platform distribusi bagi pembuat konten dan pengiklan, baik yang besar maupun kecil. Youtube menjadi pemimpin untuk situs pencarian video di internet, dengan lebih dari 100.000.000 video ditonton oleh pengunjung setiap harinya. Lebih dari 65.000 video kini diunggah setiap hari ke Youtube (Lely, 2017).

Bandung merupakan kota kecil yang memiliki penduduk yang cukup padat, karena di Kota Bandung terdapat banyak universitas negeri maupun swasta ternama yang berkualitas. Sehingga penduduk di Kota Bandung semakin beragam dan didominasi oleh anak muda yang bersekolah di Bandung. Bambang Brojonegoro selaku Kepala Badan 
Perencanaan Pembangunan Nasional mengatakan wilayah Jakarta dan Bandung bakal dihuni 70.000 .000 penduduk. Bambang mengatakan selain Jakarta, Bandung adalah salah satu tujuan urbanisasi di Indonesia. Pembangunan dan perekonomian di Bandung terus berkembang dan sebagian besar terjadi di wilayah Bandung Utara (Solehudin, 2018).

Selain itu Bandung merupakan kota yang didominasi oleh anak muda, tak heran Bandung dikenal sebagai kota kreatif yang mengapresiasi setiap ide anak muda di dalamnya. Sekarang Bandung pun sudah dicanangkan akan menjadi kota yang smart oleh Ridwan Kamil dalam hal koneksi internet dan pengetahuan yang luas harus dimiliki oleh setiap individu warga Kota Bandung.

Penelitian tentang penggunaan smartphone pernah dilakukan oleh Wahyuningsih \& Suprihartini (2017) dari Universitas Diponegoro, hasil penelitian menunjukkan bahwa semakin tinggi intensitas menggunakan smartphone dan semakin rendah pengawasan orang tua maka akan semakin tinggi perilaku antisosial pada remaja. Melalui intensitas penggunaan smartphone yang tinggi berpengaruh dalam munculnya perilaku antisosial yang tinggi, karena responden bebas mengakses apa saja yang ada di smartphone tanpa adanya batasan konten apa saja yang boleh diakses.

Menurut penelitian yang dilakukan Rahardjo (2005), bahwa orang tua perlu meningkatkan pengawasan terhadap anak tidak hanya controling roles saja tetapi juga nurturing roles, selain itu orang tua perlu memperluas kemampuan literasi media, supaya bisa mengimbangi perkembangan teknologi dan membatasi anak dalam penggunaannya.

Peneliti lainnya Syarif (2015) dari Universitas Mulawarman, dalam penelitian "Pengaruh Perilaku Penggunaan Smartphone Terhadap Komunikasi Interpersonal Siswa SMK TI Airlangga Samarinda" mengatakan "ada pengaruh yang signifikan antara perilaku pengguna smartphone terhadap komunikasi interpersonal siswa khusunya pada kelas tiga SMK TI Airlangga Samarinda, hasil penelitian menunjukkan bahwa perilaku pengguna smartphone mempunyai hubungan sedang terhadap komunikasi interpersonal siswa".

Dari hasil penelitian tentang penggunaan smartphone seperti diuraikan di atas maka perbedaannya dengan penelitian ini adalah objek penelitian yakni komunikasi interpersonal dan penelitian ini menggunakan tiga variabel yang mengarah kepada intensitas penggunaan smartphone serta pengawasan orang tua, dan objeknya ialah perilaku antisosial.

Smartphone yang biasanya digunakan oleh orang dewasa saat ini sudah banyak digunakan juga oleh remaja maupun anakanak. Dalam Wulandari (2016), "pada tahun 2014 menurut survei yang dilakukannya, persentase pengguna smartphone yang termasuk kategori usia anak-anak dan remaja cukup tinggi, yaitu 79,5 persen. Survei yang dilakukan pada 2014 itu menggambarkan pula bahwa anak menggunakan smartphone sebagian besar untuk mencari informasi hiburan, serta menjalin relasi sosial. Tingkat popularitas smartphone di kalangan anakanak tidak terlepas dari karakteristik smartphone yang memang menarik bagi anak-anak. Smarthphone menyajikan dimensi-dimensi gerak, suara, warna, dan lagu sekaligus dalam satu perangkat. Hal ini tentu saja tidak didapatkan anak-anak pada media lain, seperti buku, majalah, dan sebagainya".

Dalam laporan Norton Online Family Report 2010, "dampak positif yang didapatkan seperti merangsang indera penglihatan dan pendengaran. Selain itu, smartphone dapat memperlancar kemampuan komunikasi dan berbahasa pada anak. Joan Ganz Cooney Center di Amerika Serikat, misalnya, telah menemukan bahwa anak-anak berusia lima tahun yang menggunakan aplikasi edukasi Ipad mengalami peningkatan kosakata sekitar 27 persen, sedangkan pada anak-anak usia tiga tahun, mengalami peningkatan kosa kata sebanyak 17 persen. Di sisi lain, dampak negatif smartphone juga tidak kalah banyak. Dari segi kesehatan, penggunaan smartphone yang berlebihan dapat berdampak terhadap mata yang kering, dikarenakan kurangnya intensitas kedipan mata saat anak berhadapan dengan smartphone. Selain, anak juga menjadi lebih 
pasif, baik dalam aktivitas fisik maupun sosial. Hal ini dikarenakan anak yang cenderung beraktivitas secara individual saat bermain dengan smartphone-nya. Dampak negatif smartphone juga terkait dengan risiko cybercrime. Pada anak-anak usia 10-17 tahun di beberapa kota di Indonesia menunjukkan bahwa 55 persen anak telah menyaksikan gambar kekerasan dan pornografi, 35 persen anak mengaku dihubungi orang yang tidak dikenal, dan 28 persen anak pernah mengalami penipuan. Tentu saja data ini belum termasuk kasus-kasus penculikan atau perdagangan anak, bullying, dan pornografi pada anak yang muncul akibat penggunaan internet melalui smartphone pada anak-anak" (Wulandari, 2016).

Dari uraian di atas dapat dikatakan bahwa saat ini anak-anak Indonesia sudah sangat aktif dalam menggunakan smartphone dan banyak dari orang tua yang memberikan kebebasan anaknya menggunakan smartphone untuk membantunya mencari informasi ataupun sebagai saran hiburan anak. Banyak sekali dampak positif atau negatif bisa terjadi pada anak apabila diberikan kebebasan dalam menggunaan smartphone.

Anak TK merupakan usia yang masih cukup dini untuk menggunakan smartphone. Seiring berjalannya waktu perkembangan smartphone menjadikan anak usia dini sudah menggunakan smartphone. Penggunaan yang dilakukan oleh anak usia dini bukannya seperti yang biasa dilakukan oleh orang dewasa melainkan dengan mengakses Youtube dan melihat beragam video yang ada.

Pemberian smartphone pada anak usia dini mempunyai banyak dampak yang dapat terjadi dikemudian hari terutama pada perkembangan komunikasi interpersonal anak tersebut. Dimana anak usia dini biasanya asyik bermain dengan teman-temannya, namun dengan adanya smartphone yang diberikan bisa membuat anak malas untuk bermain di luar rumah dan memilih untuk bermain smartphone di dalam rumah. Dampak negatif tersebut bisa mengakibatkan komunikasi interpersonal anak kepada temantemannya menjadi terganggu dan tidak efektif.
Namun dari dampak negatif yang terjadi, ada pula dampak positif yang bisa terjadi pada anak usia dini saat mengakses Youtube yaitu apabila anak tersebut melakukan apa yang ditontonnya di kehidupannya sehari-hari secara positif, contoh: anak menonton serial Upin dan Ipin dan tayangan tersebut memberikan ilmu yang baik seperti menolong teman yang sedang kesusahan atau membantu orang tuanya di rumah. Hal tersebut bisa memberikan pengaruh positif pada perkembangan kemampuan komunikasi interpersonal anak di lingkungannya dan nantinya bisa membagikan pula ilmu tersebut kepada teman-temannya.

Berdasarkan latar belakang tersebut, identifikasi masalah penelitian ini: Adakah pengaruh aplikasi Youtube terhadap perkembangan kemampuan komunikasi interpersonal anak TK di Kota Bandung dan seberapa besar pengaruhnya? Tujuan penelitian ini adalah untuk menganalisis pengaruh aplikasi Youtube terhadap perkembangan kemampuan komunikasi interpersonal anak TK di Kota Bandung dan pengaruhnya terhadap perkembangan kemampuan komunikasi interpersonal anak.

\section{LANDASAN KONSEP}

\section{Komunikasi Interpersonal}

Devito (2011) menyebutkan bahwa komunikasi interpersonal adalah interaksi verbal dan nonverbal antara dua (atau kadang-kadang lebih dari dua) orang yang saling tergantung satu sama lain. Dari definisi di atas, dapat disimpulkan komunikasi interpersonal ialah pengiriman dan penerimaan pesan secara individu ke individu yang terdapat efek dan umpan baliknya.

\section{Efektivitas Komunikasi Interpersonal}

Kelebihan dari komunikasi interpersonal adalah umpan balik yang bersifat segera. Sementara itu, agar komunikasi interpersonal dapat berjalan efektif, maka harus memiliki lima aspek efektivitas komunikasi (DeVito, 2011), sebagai berikut. 
1. Keterbukaan (Openess). Mengacu pada keterbukaan dan ketersediaan komunikator untuk bereaksi secara jujur terhadap stimulus yang datang dan keterbukaan peserta komunikasi interpersonal kepada orang yang diajak untuk berinteraksi.

2. Empati (Emphaty). Empati adalah menempatkan diri kita secara emosional dan intelektual pada posisi orang lain.

3. Sikap mendukung (Supportiveness). Sikap mendukung dapat mengurangi sikap defensif komunikasi yang menjadi aspek ketiga dalam efektivitas komunikasi.

4. Sikap Positif (Positiveness). Seseorang yang memiliki sikap diri yang positif, maka ia pun akan mengomunikasikan hal yang positif. Sikap positif juga dapat dipicu oleh dorongan (stroking) yaitu perilaku mendorong untuk menghargai keberadaan orang lain.

5. Kesetaraan (Equality). Kesetaraan merupakan pengakuan bahwa masingmasing pihak memiliki sesuatu yang penting untuk disumbangkan. Komunikasi interpersonal merupakan pengiriman pesan dari seseorang dan diterima oleh orang lain dengan efek dan umpan balik yang langsung.

\section{Media Massa}

McQuail (2010) menyatakan ada enam perspektif tentang peran media massa dalam konteks masyarakat modern, yaitu sebagai berikut.

1. Media massa sebagai sarana belajar untuk mengetahui berbagai informasi dan peristiwa. Ia ibarat "jendela" untuk melihat apa yang terjadi di luar kehidupan.

2. Media massa adalah refleksi fakta, terlepas dari ras suka atau tidak suka. Ia ibarat "cermin" peristiwa yang ada dan terjadi di masyarakat ataupun dunia.

3. Media massa sebagai filter yang menyeleksi berbagai informasi dan issue yang layak mendapat perhatian atau tidak.

4. Media massa sebagai penunjuk arah berbagai ketidakpastian atau alternatif yang beragam.
5. Media massa sebagi sarana untuk menyosialisasikan berbagai informasi atau ide kepada publik untuk memperoleh tanggapan/umpan balik.

6. Media massa sebagai interkulator, tidak sekedar tempat "lalu lalang" informasi tetapi memungkinkan terjadinya komunikasi yang interaktif.

Youtube, merupakan salah satu jenis media sosial yang telah disebutkan di atas, Youtube termasuk ke dalam jenis media sharing. Begitu banyak video telah dibagikan melalui situs Youtube. Saat ini pengguna Youtube rata-rata dalam setiap menitnya mengunggah 72 jam video ke situs ini, dan hingga kini Youtube menguasai 60 persen dari jumlah total penikmat video online dan menjadi situs video content sharing terbesar di dunia. Youtube telah diakses dari berbagai belahan dunia dan memiliki empat milyar video serta 800.000 .000 pengguna (Puntoadi, 2011).

Youtube adalah situs video online yang menyediakan berbagai informasi berupa gambar bergerak atau video bahkan juga interaktif. Youtube bisa diakses oleh siapa saja yang ingin mendapatkan informasi video dan menontonnya langsung. Pengunjung juga dapat berpartisipasi dengan cara mengunggah video ke server Youtube, dan kemudian membaginya ke seluruh dunia.

Baskoro (2009) menyebutkan Youtube merupakan layanan file sharing berbasis web audio-video yang memungkinkan individu untuk dapat:

- Membangun profil publik atau semi publik dalam sistem yang dibatasi.

- Mengartikulasikan daftar pengguna lain dengan siapa mereka akan berbagi sambungan.

- Melihat daftar koneksi yang dibuat oleh orang lain dalam sistem tersebut.

\section{Komunikasi}

Komunikasi berlangsung dalam lingkungan dan konteks tertentu dalam suasana formal atau informal, pada ruang dan waktu tertentu. Ruang dan waktu tersebut bisa menjadi pendukung kegiatan komunikasi, bisa menyediakan peluang untuk berkomunikasi, namun bisa juga memunculkan hambatan komunikasi. 
Komunikasi bisa dalam kelompok kecil dan bisa juga dalam kelompok besar, bisa dalam lingkungan dengan jumlah terbatas seperti di ruang kelas, bisa juga dengan jumlah orang yang banyak seperti berkomunikasi di lingkungan masyarakat.

Kegiatan pendidikan pada dasarnya membelajarkan manusia untuk mengenal Tuhan, diri, dan lingkungan sosial serta lingkungan alamiahnya. Pembelajaran ini dilakukan di rumah, masyarakat, dan sekolah. Manusia juga dibelajarkan untuk mengetahui diri dan lingkungan sosialnya. Umpamanya dibelajarkan untuk mengetahui interaksinya dengan sesama, dimensi kejiwaannya, perilakunya, dan anatomi tubuhnya.

Dalam proses pembelajaran, baik di sekolah maupun di tempat lain, pasti terjadi komunikasi. Membelajarkan orang lain bukan sekedar soal apa yang diajarkan dan bagaimana membelajarkannya. Karena di dalamnya ada komunikasi, dalam setiap interaksi edukasi seperti itu akan berlangsung proses komunikasi. Komunikasi anak dan orang tua dalam pembelajaran di rumah atau guru dan siswa di sekolah.

Komunikasi dilakukan manusia bukan hanya untuk menyampaikan atau saling bertukar pesan/informasi, melainkan ada tujuan untuk membangun dan memelihara relasi. Dalam praktik pembelajaran pun, komunikasi yang dilakukan guru dan siswa bukan hanya proses pertukaran dan penyampaian materi pembelajaran, melainkan ada dimensi relasi guru dan siswa. Baiknya relasi guru dan siswa menjadi prasyarat utama terciptanya proses pembelajaran yang efektif. Di sekolah, guru dan siswa merupakan pelaku utama dalam proses pembelajaran. Kedua pelaku ini menjalankan peran penting dalam mencapai tujuan pembelajaran yang berlangsung di sekolah. Oleh karena itu, antara guru dan siswa harus terjalin relasi edukasi yang baik. Beberapa penelitian menunjukkan bahwa relasi guru dan siswa berdampak pada proses pembelajaran (Wang; Haertel; Walberg dalam Iriantara \& Surachman, 2006).

\section{Pengertian Anak Prasekolah}

Anak usia prasekolah merupakan fase perkembangan individu sekitar usia dua sampai enam tahun, ketika anak mulai memiliki kesadaran tentang dirinya sebagai pria atau wanita, mengenal beberapa hal yang dianggap berbahaya untuk dirinya. Pada saat memasukin fase ini anak mengalami perkembangan dalam berbagai hal, di antaranya perkembangan fisik, perkembangan intelektual, perkembangan emosional, perkembangan bahasa, perkembangan sosial, perkembangan bermain, perkembangan moral, dan perkembangan kesadaran beragama.

Perkembangan kognitif pada usia taman kanak-kanak berada pada periode pre operasional, yaitu tahapan dimana anak belum mampu menguasai operasi mental secara logis. Periode ini ditandai dengan berkembangnya representasional yaitu kemampuan untuk menggunakan sesuatu untuk merepresentasikan sesuatu yang lain menggunakan simbol (kata-kata, gesture atau bahasa tubuh, dan benda). Meskipun berpikir melalui simbol ini dipandang lebih maju dari berpikir periode sensorimotor, namun kemampuan berpikir ini masih mengalami keterbatasan.

Perkembangan moral, anak usia TK memiliki dasar tentang sikap moralitas terhadap kelompok sosialnya (orang tua, saudara, dan teman sebaya). Melalui pengalaman berinteraksi dengan orang lain, anak belajar memahami tentang kegiatan atau perilaku mana yang baik (boleh, diterima, atau disetujui) atau buruk (tidak boleh, ditolak, atau tidak disetujui). Berdasarkan pemahamnnya itu, maka pada masa ini anak harus dilatih atau dibiasakan mengenai bagaimana dia harus bertingkah laku. Pada usia prasekolah berkembang kesadaran sosial anak, yang meliputi sikap simpati, murah hati, atau sikap kepedulian terhadap kesejahteraan orang lain, sikap ini merupakan lawan dari egosentris.

\section{Kerangka Pemikiran dan Hipotesis}

Kerangka pemikiran merupakan suatu model konseptual tentang bagaimana sebuah teori bisa berhubungan dengan berbagai faktor yang telah didefinisikan sebagi masalah yang penting. Kerangka pemikiran yang baik akan menjelaskan secara teoritis pertautan antar variabel yang akan diteliti. 


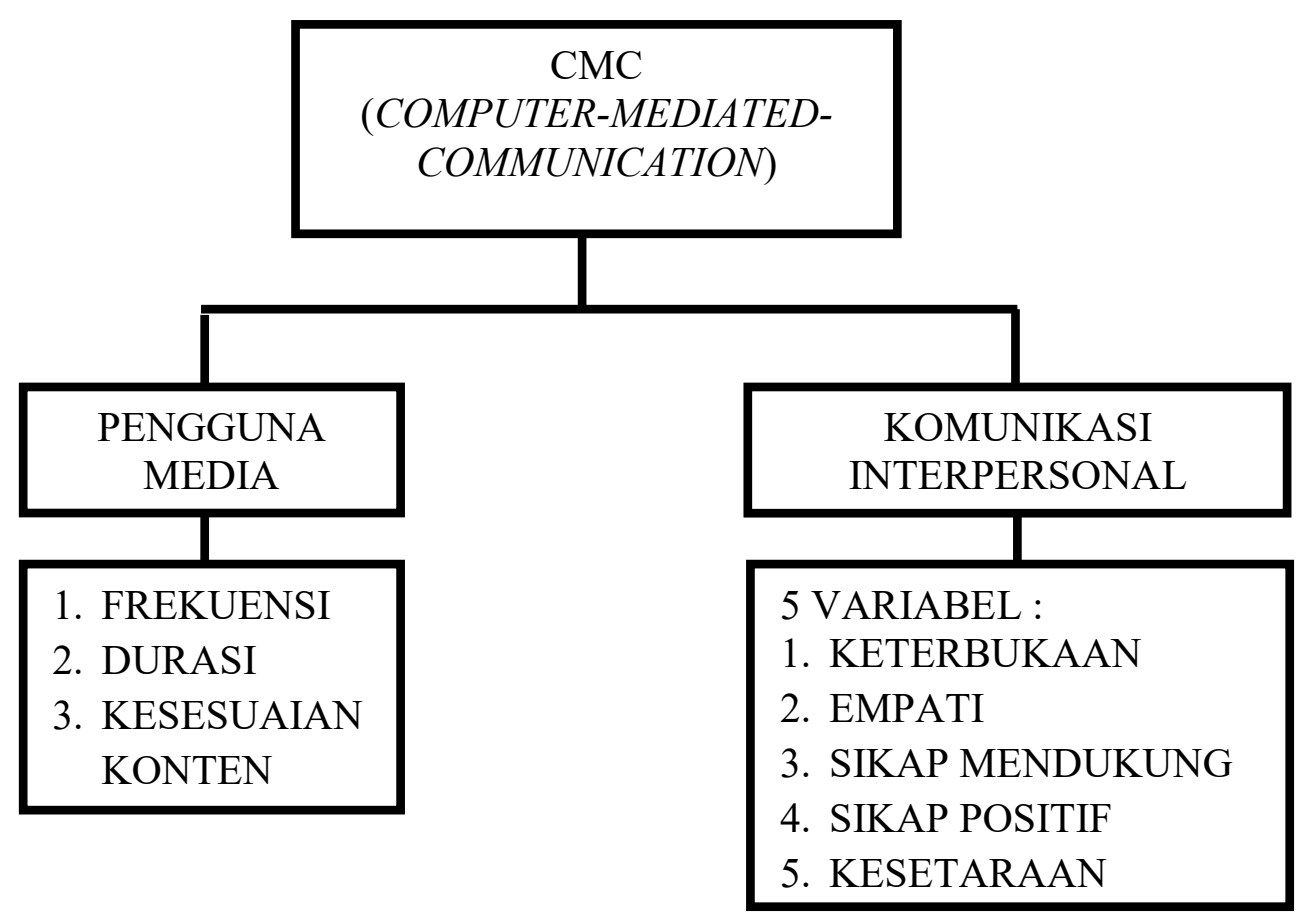

Gambar 1. Kerangka Pemikiran

Gambar 1 adalah kerangka pemikiran dari penelitian ini. Untuk membuktikan pengaruh atau tidaknya penggunaan smartphone terhadap perkembangan kemampuan komunikasi interpersonal anak TK di Kota Bandung, maka hipotesis penelitian ini adalah.

- $\mathrm{Ho}=$ artinya tidak ada pengaruh aplikasi Youtube (X) terhadap perkembangan kemampuan komunikasi interpersonal anak TK (Y).

- $\mathrm{Ha}=$ artinya, terdapat pengaruh aplikasi Youtube (X) terhadap perkembangan kemampuan komunikasi interpersonal anak TK (Y).

\section{METODE PENELITIAN}

Penelitian ini menggunakan paradigma positivisme Neuman (2003) yang berpandangan bahwa teori terbentuk dari seperangkat hukum universal yang berlaku. Dalam pendekatan ini, peneliti memulai dengan sebuah hubungan sebab akibat umum yang diperoleh dari teori umum. Kemudian, menggunakan idenya untuk memperbaiki penjelasan tentang hubungan tersebut dalam konteks yang lebih khusus.
Pendekatan penelitian ini adalah deskriptif, yaitu melakukan analisis hanya sampai deskripsi, serta menganalisis dan menyajikan fakta secara sistematik sehingga dapat lebih mudah dipahami dan disimpulkan. Simpulannya memiliki dasar faktual yang jelas sehingga dapat dikembalikan langsung pada data yang diperoleh. Uraian simpulan didasari oleh angka yang tidak diolah secara mendalam.

Teknik pengumpulan data dalam penelitian kuantitatif adalah dengan metode survei, peneliti menggunakan kuesioner sebagai instrument penelitiannya, dimana responden diminta untuk memberi jawaban singkat yang sudah tertulis di dalam kuisioner atau angket untuk kemudian jawaban dari seluruh responden nantinya diolah menggunakan teknik kuantitatif.

Selain menggunakan teknik survei peneliti juga penggunakan teknik wawancara dimana penulis akan memberikan pertanyaan dari kuisioner kepada anak TK yang dibutuhkan pendekatan mendalam agar hasil dari penelitian ini bisa valid. Sugiyono (2016) menyimpulkan bahwa metode penelitian survei adalah metode penelitian kuantitatif yang digunakan untuk mendapatkan data 
yang terjadi pada masa lampau atau saat ini, tentang keyakinan, pendapat, karakteristik, perilaku, hubungan variabel dan untuk menguji beberapa hipotesis tentang variabel sosiologis dan psikologis dari sampel yang diambil dari populasi tertentu, teknik pengumpulan data dengan pengamatan (wawancara atau kuesioner) yang tidak mendalam, dan hasil penelitian cenderung untuk digeneralisasikan.

Dalam penelitian ini hanya terdapat variabel bebas yaitu pengaksesan Youtube di smartphone $(\mathrm{X})$ dan variabel terikat yaitu perkembangan kemampuan komunikasi interpersonal $(\mathrm{Y})$.

Variabel bebas (independent variable) adalah variabel yang menjadi sebab atau merubah/memengaruhi variabel lain (dependent variable). Juga sering disebut dengan variabel bebas, prediktor, stimulus, eksogen, atau antecendent (Siregar, 2013).
Dalam penelitian ini pengaksesaan Youtube di smartphone yang merupakan variabel (X) mempunyai beberapa sub variabel yaitu frekuensi, durasi, dan konten.

Variabel terikat (dependent variable) merupakan variabel yang dipengaruhi atau menjadi akibat karena adanya variabel lain (variabel bebas) (Siregar, 2013). Dalam penelitian ini perkembangan kemampuan komunikasi interpersonal yang merupakan variabel (Y) mempunyai beberapa sub variabel yaitu interaksi intim, percakapan sosial, wawancara.

Populasi dalam penelitian ini adalah siswa Taman Kanak-Kanak (TK) B dari beberapa TK yang berada di Kota Bandung seperti TK BPI, TK Patriot, TK Negeri Pembina, TK Badak Putih, dan TK AlQolam, dimana saat ini anak TK sudah tidak asing lagi dengan penggunaan smartphone.

Tabel 1

Operasionalisas Variabel

\begin{tabular}{|c|c|c|c|}
\hline Variabel & Sub Variabel & Indikator & Skala \\
\hline \multirow{3}{*}{$\begin{array}{l}\text { Aplikasi Youtube di } \\
\text { smartphone }(\mathrm{X})\end{array}$} & Frekuensi & $\begin{array}{l}\text { Lama waktu menggunakan smartphone (perhari). } \\
\text { Lama menggunakan smartphone (perjam). }\end{array}$ & Ordinal \\
\hline & Durasi & $\begin{array}{l}\text { Tahu tentang Youtube. } \\
\text { Lama mengakses Youtube. }\end{array}$ & Ordinal \\
\hline & Konten & $\begin{array}{l}\text { Cara menggunakan smartphone (camera, video). } \\
\text { Video yang suka dilihat di Youtube. } \\
\text { Alasan menyukai film tersebut. }\end{array}$ & Ordinal \\
\hline \multirow{3}{*}{ Komunikasi Interpersonal } & Interaksi Intim & $\begin{array}{l}\text { Berkomunikasi dengan teman di sekolah atau di } \\
\text { rumah. } \\
\text { Berkomunikasi dengan orang tua. }\end{array}$ & Ordinal \\
\hline & $\begin{array}{l}\text { Percakapan } \\
\text { Sosial }\end{array}$ & $\begin{array}{l}\text { Berbicara dengan teman di sekolah atau di rumah } \\
\text { yang membuat hati senang. } \\
\text { Berbicara tatap muka. }\end{array}$ & Ordinal \\
\hline & Wawancara & Melakukan aktivitas selain mengakses Youtube. & Ordinal \\
\hline
\end{tabular}


Tabel 2

Jumlah Siswa TK B di beberapa TK yang Berada di Kota Bandung

\begin{tabular}{clc} 
No & Nama Sekolah & Jumlah Siswa \\
\hline $\mathbf{1}$ & TK AL-Qolam & 25 \\
$\mathbf{2}$ & TK BPI & 45 \\
$\mathbf{3}$ & TK Patriot & 36 \\
$\mathbf{4}$ & TK Badak Putih & 32 \\
$\mathbf{5}$ & TK Negri Pembinaan & 100 \\
Jumlah Siswa & 238
\end{tabular}

Sumber: Kepala Sekolah Setiap TK

Pengambilan sampel harus dilakukan sedemikian rupa sehingga diperoleh sampel yang benar-benar dapat mewakili (representatif) dan dapat menggambarkan keadaan populasi yang sebenarnya, maka dalam penentuan sampel digunakan rumus slovin, sebagai berikut.

$$
n=\frac{\mathrm{N}}{1+\mathrm{Ne}^{2}}
$$

Sumber: Siregar (2013)

Keterangan:

$n$ : Ukuran Sampel

$\mathrm{N}$ : Ukuran Populasi

e : Perkiraan tingkat kesalahan

Dalam penelitian ini digunakan tingkat kesalahan (e) sebesar 10\%. Apabila dihitung menggunakan rumus Slovin maka akan didapatkan sebagai berikut.

$$
\begin{gathered}
n=\left[\frac{238}{1+238(0.1)^{2}}\right] \\
n=\left[\frac{238}{1+2.38}\right] \\
n=\left[\frac{238}{3.38}\right] \\
n=70.414 \\
n=70
\end{gathered}
$$

Dari perhitungan di atas dapat disimpulkan bahwa nilai $\mathrm{n}$ adalah 70 sehingga membutuhkan 70 responden. Setiap TK memiliki tiga kelas untuk TK B, maka akan dibutuhkan empat responden dari setiap kelasnya.

Sumber data primer dilakukan melalui survei ke beberapa responden dengan memberikan kuesioner. Kuesioner merupakan teknik pengumpulan data yang dilakukan dengan cara memberikan sejumlah pertanyaan atau pernyataan tertulis kepada responden untuk dijawabnya (Sugiyono, 2014). Dalam penelitian ini, peneliti memberikan kuesioner kepada siswa TK B di TK BPI, TK Patriot, TK Negri Pembina, TK Badak Putih, dan TK Al-Qolam. Kuesioner dibagikan secara langsung dengan cara mengunjungi sekolah TK dan langusng bertemu dengan siswa-siswa dari TK tersebut.

Data sekunder penelitian ini yaitu penelitian terdahulu yang dilakukan oleh peneliti sebelumnya, jurnal nasional dan internasional, serta buku, dan juga website yang terpercaya.

Adapun uji validitas dengan menggunakan program SPSS versi 23.0. Hasil uji reliabilitas dengan bantuan program SPSS versi 23.0 untuk variabel $\mathrm{X}$ disajikan pada Tabel 3. Hasil dari uji validitas dan reliabilitas terhadap $\mathrm{X}$ diatas menyatakan bahwa sembilan pertanyaan valid dan reliabel atau bisa digunakan dan konsisten dalam penelitian. 
Tabel 3

Hasil Uji Reliabilitas X

\begin{tabular}{cc}
\multicolumn{2}{c}{ Hasil Uji Reliabilitas X } \\
\hline \multicolumn{2}{c}{ Reliability Statistics } \\
\hline Cronbach's Alpha & N of Items \\
.789 & 9 \\
\hline
\end{tabular}

Tabel 4

Hasil Uji Reliabilitas Y

\begin{tabular}{cc}
\multicolumn{2}{c}{ Hasil Uji Reliabilitas Y } \\
\hline \multicolumn{2}{c}{ Reliability Statistics } \\
\hline Cronbach's Alpha & N of Items \\
.747 & 7 \\
\hline
\end{tabular}

Tabel 5

Kriteria Interprestasi Skor

\begin{tabular}{ccc}
\hline No. & Persentase & Kriteria Penilaian \\
\hline 1 & $\mathbf{2 5 \%}-\mathbf{4 3 , 7 5 \%}$ & Sangat Rendah \\
2 & $\mathbf{7 3 3 , 7 5 \% - 6 2 , 5 \%}$ & Rendah \\
3 & $>\mathbf{6 2 , 5} \%-\mathbf{8 1 , 2 5 \%}$ & Tinggi \\
4 & $>\mathbf{8 1 , 2 5 \%}-\mathbf{1 0 0 \%}$ & Sangat Tinggi \\
\hline
\end{tabular}

Sedangkan hasil uji reliabilitas dengan bantuan program SPSS versi 23.0 untuk variabel Y disajikan pada Tabel 4. Adapun dari hasil uji validitas dan reliabilitas terhadap $\mathrm{Y}$ tersebut menyatakan bahwa tujuh pertanyaan valid dan reliabilitas atau bisa digunakan dan konsisten dalam penelitian.

Pendekatan penelitian yang digunakan adalah pendekatan kuantitatif dengan menggunakan teknik analisis data yang akan dilakukan dengan teknik statistik deskriptif. Pada penelitian ini, penulis menggunakan kuesioner yang masing-masing pertanyaan disertai dengan empat kemungkinan jawaban yang harus dipilih oleh responden.

Dari jawaban yang didapatkan kemudian disusun kriteria penilaian untuk setiap pertanyaan berdasarkan presentase dengan langkah-langkah sebagai berikut.

- Nilai kumulatif adalah jumlah dari setiap pertanyaan yang merupakan jawaban dari 70 responden.

- Menghitung jumlah kumulatif terbesar dan terkecil. Jumlah responden adalah
70 responden dengan skala pengukuran terbesar adalah 4 dan skala pengukuran terkecil 1.

○ Jumlah kumulatif terbesar $70 \times 4=$ 280.

○ Jumlah kumulatif terkecil $70 \times 1=$ 70.

- Menentukan nilai persentase terbesar dan terkecil.

○ Nilai persentase terbesar, $280 / 280 \mathrm{x}$ $100 \%=100 \%$.

- Nilai persentase terkecil, $70 / 280 \mathrm{x}$ $100 \%=25 \%$.

- Menghitung nilai rentang.

- Nilai rentang yaitu nilai persentase terbesar dikurangi nilai persentase terkecil, jadi $100 \%-25 \%=75 \%$

- Jika nilai rentang dibagi 4 skala pengukuran, maka akan diperoleh nilai interval persentase sebesar $18,75 \%$ sehingga diperoleh kriteria interpresentasi skor (Tabel 5). 


\section{HASIL PENELITIAN DAN PEMBAHASAN}

Dari hasil penelitian yang dilakukan peneliti indikator pada $\mathrm{X}_{1}$ mencapai kategori sangat baik, yakni dengan skor 477 atau $79,8 \%$. Dapat diartikan bahwa anak TK di Kota Bandung menyetujui bahwa frekuensi penggunaan smartphone mereka lakukan secara rutin. Frekuensi tersebut dilakukan di luar sekolah atau ketika di rumah, walaupun sudah diberi batasan oleh orang tua, mereka masih menggunakannya dan bisa dikatakan tingkat penggunaan smartphone yang mereka lakukan setiap hari tinggi.

Secara keseluruhan hasil tanggapan responden dan nilai presentasi yang didapatkan mengenai frekuensi penggunaan aplikasi Youtube sebesar $80,6 \%$. Nilai persentase tanggapan responden variabel frekuensi berada pada interval $62,50 \%$ $81,25 \%$ dengan kategori tinggi sesuai dengan garis kontinum persentasi tanggapan responden yang telah ditentukan penulis.

Pada penelitian ini komunikasi interpersonal dijadikan sebagai variabel $\mathrm{Y}$ mengingat bahwa peneliti ingin melihat bagaimana komunikasi interpersonal anak TK di Kota Bandung dari frekuensi mereka yang mengakses Youtube di smartphone. Kuesioner yang ditanyakan kepada 70 responden dengan karakteristik yang telah ditentukan oleh peneliti. Hasil perhitungan tanggapan responden mengenai variabel komunikasi interpersonal memiliki rata-rata nilai persentase termasuk dalam kategori tinggi. Dari tujuh pertanyaan pada kuesioner mengenai variabel komunikasi interpersonal, pertanyaan nomor 16 memiliki skor sangat tinggi yakni 254 atau 90,7\%. Hal ini berarti bahwa anak TK di Kota Bandung sehariharinya setiap pulang sekolah selalu menceritakan kepada orang tuanya apa yang terjadi di sekolah ataupun setelah bermain dengan teman-temannya. Hal itu haruslah dibiasakan agar anak terbiasa terbuka kepada orang tuanya dan orang tua mengetahui apa yang terjadi dengan anak.

Disimpulkan bahwa perkembangan komunikasi interpersonal yang terjadi dalam diri anak semakin bagus dengan selalu menceritakan apa saja kepada orang tua sehingga komunikasi berjalan dengan baik seperti yang selalu dibangun antar keduanya, namun adanya kendala dalam komunikasi antar anak dan orang tua adalah ketika keduanya sudah mulai memainkan smartphone masing-masing seperti memiliki dunia sendiri.

Komunikasi interpersonal terjadi bukan hanya pada anak dan orang tua tapi juga pada lingkungan di sekitar tempat mereka berada, seperti di sekolah. Saat berada di sekolah anak juga harus menjalin komunikasi yang baik antara dirinya dengan orang-orang yang berada di sekitarnya. Seperti di sekolah mereka harus menjalin komunikasi yang baik dengan guru dan teman-teman di kelas.

Setelah proses olah data didapat nilai persentase tanggapan responden mengenai variabel $\mathrm{Y}$ tersebut berada pada interval $62,50 \%$ - 81,25\% dengan kategori tinggi sesuai dengan garis kontinum persentase tanggapan responden yang telah ditentukan oleh peneliti sebelumnya. Ini menunjukkan kalau perkembangan komunikasi interpesonal yang terjadi sudah baik untuk usia dini.

Dari dampak negatif yang dapat terjadi apabila terlalu sering mengakses Youtube pada anak usia dini, seperti timbulnya sikap individual. Ada pula dampak positif yang bisa terjadi dan bisa meningkatkan kemampuan komunikasi interpersonal sang anak kepada lingkungan sekitarnya. Apabila dikaitkan dengan lima efektivitas komunikasi intepersonal menurut DeVito dapat disimpulkan bahwa adanya pengaruh positif yang terjadi pada perkembangan kemampuan komunikasi interpersonal anak di usia dini, antara lain.

\section{Keterbukaan}

Pada poin yang pertama bisa disimpulkan adanya pengaruh yang terjadi yaitu anak usia dini menjadi terbuka kepada kedua orang tua nya tentang kegiatan yang terjadi setiap harinya, mulai dari lingkungan tempat dia bermain sampai dengan tempat dia belajar.

\section{Empati}

Pada poin kedua yang dapat disimpulkan pengaruh dari pengaksesan Youtube yang dilakukan oleh anak usia dini 
adalah lebih peduli dengan lingkungan sekitar. Contoh membantu teman-teman di sekolah apabila sedang jatuh, atau memisahkan temannya yang sedang terjadi pertengkaran dengan cara melaporkan kepada guru agar bisa dipisahkan.

\section{Sikap Mendukung}

Pada poin ketiga dapat disimpulkan pengaruh dari pengaksesan Youtube yang dilakukan oleh anak usia dini adalah selalu mendukung apabila sedang adanya kegiatan yang dilakukan di lingkungannya. Contoh apabila temannya sedang mengikuti suatu perlombaan satu sama lain saling mendukung dengan memberikan semangat. Contoh kedua seperti sedang adanya perayaan 17 Agustusan untuk memperingati HUT RI dan di lingkungannya mengadakan perlombaan, anak tersebut mengikuti acara yang diadakan untuk mendukung dan menumbuhkan rasa nasionalisme dalam diri sang anak.

\section{Sikap Positif}

Anak usia dini selalu mencontoh apa yang terjadi di sekitarnya ataupun apa yang ia tonton, seperti contoh memberikan perilaku untuk membuang sampah pada tempatnya. Hal tersebut bisa menjadikan anak selalu melakukan hal positif, sehingga nanti dapat dicontoh oleh yang lainnya. Dari hal tersebut anak sudah memberikan hal positif bagi dirinya ataupun lingkungannya.

\section{Kesetaraan}

Pada poin ini dapat diambil contoh kecil yaitu saat anak menceritakan kegiatan yang telah terjadi kepada orang tuanya, dan orang tua memberikan respon langsung tentang apa yang diceritakan oleh anak sehingga anak menjadi senang dan lebih bersemangat untuk selalu bercerita dan terbuka kepada orang tuanya.

Pengaksesan Youtube di smartphone merupakan variabel independen (X) pada penelitian ini dan komunikasi interpersonal merupakan variabel dependen $(\mathrm{Y})$. Peneliti berusaha untuk mengukur seberapa besar pengaruh pengaksesan Youtube terhadap perkembangan komunikasi interpersonal anak TK di Kota Bandung melalui penelitian ini.
Dalam menghitung besar pengaruh penggunaan smartphone terhadap perkembangan komunikasi interpersonal anak TK di Kota Bandung, peneliti menggunakan analisis regresi linear sederhana, koefisien Determinasi dan Uji Hipotesis (Uji t).

Setelah menghitung tanggapan responden dilakukan perhitungan statistik menggunakan analisis regresi linear sederhana, persamaan yang diperoleh adalah $\mathrm{Y}=1,325+0,479 \mathrm{X}$ dan persamaan tersebut berarti bahwa jika mengakses Youtube (X) bernilai nol maka rata-rata mengakses Youtube bernilai 0,152. Kemudian untuk koefisien regresi memiliki arti bahwa jika variabel mengakses Youtube (X) meningkat sebesar satu-satuan, maka sikap (Y) akan meningkat sebesar 0,479. Selanjutnya peneliti menghitung hasil koefisien determinasi yang memperoleh nilai sebesar $35,1 \%$. Hal ini menunjukkan bahwa besarnya pengaruh variabel pengakses Youtube (X) terhadap perkembangan komunikasi interpersonal (Y) adalah sebesar 35,1\% sedangkan sisanya sebesar $64,9 \%$ dipengaruki oleh faktor lain yang tidak diteliti dalam penelitian ini. Selanjutnya perhitungan Uji Hipotesis yang menggunakan Uji t diperoleh nilai thitung sebesar 6,066 yang berarti lebih besar dari t tabel yaitu 1,995 , dengan persentase pengaruh sebesar 47,9\% maka dapat disimpulkan bahwa variabel pengakses Youtube berpengaruh secara simultan terhadap variabel perkermbangan komunikasi interpersonal anak TK di Kota Bandung.

\section{PENUTUP}

\section{Simpulan}

Pengaruh durasi saat mengakses Youtube terhadap komunikasi interpersonal anak TK di Kota Bandung berada pada kategori sangat baik.

Pengaruh konten pada aplikasi Youtube terhadap komunikasi interpersonal anak TK di Kota Bandung berada pada kategori baik. Oleh karena itu orang tua mengawasi dan membatasi penggunaan smartphone yang digunakan anaknya.

Dari hasil perhitungan keseluruhan, penelitian ini menjelaskan bahwa pengaruh 
pengaksesan Youtube terhadap perkembangan komunikasi interpersonal anak TK di Kota Bandung sangat baik, karena mereka menjadikan Youtube sebagai media untuk belajar dan mencari informasi serta hiburan. Komunikasi interpersonal seorang anak TK juga didorong dari lingkungan sekitarnya. Dengan hasil yang didapatkan bisa disimpulkan komunikasi interpersonal anak-anak TK berkembang dengan baik walaupun mereka sering mengakses Youtube setelah pulang sekolah tapi tidak lepas dari pengawasan orang tua mereka.

\section{Saran}

\section{Saran Teoretis}

Untuk calon peneliti yang tertarik dalam melakukan penelitian mengenai pengaruh aplikasi Youtube, diharapkan dapat melakukan penelitian lanjutan dengan variabel yang lain yang belum diteliti selain komunikasi interpersonal. Calon peneliti juga diharapkan dapat melakukan penelitian lanjutan dengan menggunakan objek penelitian yang berbeda agar mendapatkan hasil yang lebih baik lagi.

\section{Saran Praktis}

Saran untuk sekolah TK di Kota Bandung lainnya sebaiknya bisa memberikan materi pelajaran mengenai bahaya penggunaan smartphone yang berlebihan dan dampak yang bisa terjadi apabila menggunakan smartphone yang berlebihan.

Saran untuk sekolah di Kota Bandung agar lebih memberikan pelajaran yang bisa memunculkan interaksi antara murid yang satu dengan murid yang lainnya agar komunikasi interpersonal antara murid lebih baik dan tidak adanya sifat individual.

Saran untuk orang tua yang memiliki anak-anak usia dini agar bisa memantau dan mengetahui semua kegiatan yang dilakukan anak-anaknya. Memberikan batasan serta mengawasan yang ekstra apabila anak sedang menggunakan smartphone secara berlebihan dan orang tua dituntut untuk bisa memberikan tontonan yang mendidik kepada anakanaknya.

\section{DAFTAR PUSTAKA}

Baskoro, A. (2009) Panduan Praktis Searching di Internet. Jakarta Selatan., PT TransMedia.

DeVito, J.A. (2011) Komunikasi Antar Manusia. Tangerang Selatan, Karisma Publishing Group.

Iriantara, Y. \& Surachman, Y.A. (2006) Public Relations Writing. Bandung, Simbiosa Rekatama Media.

Lely, M. (2017) OKEZONE INNOVATION: Kisah YouTube yang Didirikan 3 Mantan Karyawan PayPal. [Online]. 2017. techno.okezone.com. Available from: https://techno.okezone.com/read/2017/08/25 /207/1763207/okezone-innovation-kisahyoutube-yang-didirikan-3-mantankaryawan-paypal [Accessed: 4 April 2018].

McQuail, D. (2010) McQuail's Mass Communication Theory. 6th edition. Thousand Oaks, CA, Sage Publications, Ltd.

Muhaemin, A. (2017) 5 Situs yang Paling Banyak Dikunjungi. [Online]. 2017. Pikiran Rakyat. Available from: http://www.pikiranrakyat.com/hidup-gaya/2017/10/20/5-situsyang-paling-banyak-dikunjungi-411970 [Accessed: 4 April 2018].

Neuman, L.W. (2003) Social Research Methods: Qualitative and Quantitative Approaches. Allyn and Bacon.

Pratama, A.S.P. (2017) Hubungan Kecanduan Bermain Game Online Pada Smartphone (Mobile Online Games) Terhadap Prestasi Akademik Mahasiswa Angkatan 2013 Fakultas Kedokteran Universitas Lampung. [Online]. Lampung, Universitas Lampung. Available from: http://digilib.unila.ac.id/25363/.

Puntoadi, D. (2011) Meningkatkan Penjualan Melalui Media Sosial. Jakarta, PT. Gramedia Pustaka Utama.

Rahardjo, T. (2005) Menghargai Perbedaan Kultural: Mindfulness dalam Komunikasi Antaretnis. Mu'ammar Ramadhan (ed.). Yogyakarta, Pustaka Pelajar.

Siregar, S. (2013) Metode Penelitian Kuantitatif. Jakarta, PT Fajar Interpratama Mandiri.

Solehudin, M. (2018) 2045, Jumlah Penduduk Bandung dan Jakarta Diprediksi 70 Juta. [Online]. 2018. detikNews. Available from: https://news.detik.com/berita-jawa-barat/d3953159/2045-jumlah-penduduk-bandungdan-jakarta-diprediksi-70-juta [Accessed: 4 April 2018].

Sugiyono (2014) Metode Penelitian Kuantitatif, Kualitatif, dan $R \& D$. Bandung, Alfabeta.

Syarif, N. (2015) Pengaruh Perilaku Pengguna 
Smartphone Terhadap Komunikasi Interpersonal Siswa SMK TI Airlangga Samarinda. eJournal Ilmu Komunikasi. [Online] 3 (2), 213-227. Available from: http://ejournal.ilkom.fisipunmul.ac.id/site/?p=1974.

Wahyudi, A. (2017) Indonesia, Raksasa Teknologi Digital Asia. [Online]. 2017. Katadata.co.id. Available from: https://katadata.co.id/opini/2015/09/29/indo nesia-raksasa-teknologi-digital-asia.

Wahyuningsih, D. \& Suprihartini, T. (2017) Pengaruh Intensitas Penggunaan Smartphone dan Pengawasan Orang Tua Terhadap Perilaku Antisosial (Kasus Penggunaan Smartphone dan Pengawasan
Orang Tua SMP Purnama 3 Semarang Terhadap Munculnya Perilaku Antisosial). Interaksi Online. [Online] 18 (2), 1-12. Available from: https://ejournal3.undip.ac.id/index.php/inter aksi-online/article/view/16220.

Wulandari, P.Y. (2016) Anak Asuhan Gadget. [Online]. 2016. Liputan6.com. Available from:

https://www.liputan6.com/health/read/24603 30/anak-asuhan-gadget [Accessed: 4 April 2018]. 